\title{
EXHAUST TEMPERATURE ANALYSIS OF UAV PROPELLER MATERIALS
}

\section{ANALISA PENGARUH TEMPERATUR GAS BUANG TERHADAP MATERIAL PROPELLER UAV}

\author{
Suherman Mukti ${ }^{1}$, Fadli C. Megawanto ${ }^{1}$, Hari Artha ${ }^{1}$ \\ ${ }^{1}$ Center of Technology for Defense and Security Industries \\ Agency for The Assessment and Application of Technology \\ e-mail: suherman.mukti@bppt.go.id
}

\begin{abstract}
This paper presents an exhaust temperature analysis of a UAV Propeller Material to maintain the performance of the propulsion system during operation, especially in a long-range condition. A pusher Propeller experiences direct contact with heat from the exhaust gas. In this study, a Beechwood material with a protective layer of corrosion prevention is used as a propeller blade that works at a range of high temperatures. An experimental methodology was carried out to analyse the strength and propeller deformation. The results of this experimental study show that conservatively the propeller will be heated to $32.9^{\circ} \mathrm{C}$. Since this is below the temperature limit, the exhaust gas to pusher propeller on UAV does not affect the propeller performance.
\end{abstract}

Key Words: Exhaust; Temperature; UAV; Propeller; Wood

\begin{abstract}
Abstrak
Makalah ini memaparkan analisa pengaruh temperatur gas buang terhadap material Propeler UAV untuk menjaga kinerja sistem propulsi selama pengoperasian, khususnya pada pengoperasian jarak jauh. Propeller sebagai tenaga pendorong mengalami kontak langsung dengan panas dari gas buang. Pada penelitian ini digunakan material Beechwood dengan lapisan pelindung pencegah korosi pada propeller yang bekerja pada rentang temperatur tinggi. Metodologi eksperimental dilakukan untuk menganalisis kekuatan dan deformasi dari propeller. Hasil studi eksperimental ini menunjukkan bahwa secara konservatif, propeller akan dipanaskan hingga $32,9^{\circ}$ C. Karena berada di bawah batas suhu maksimal operasional, maka gas buang ke propeller pendorong UAV tidak mempengaruhi kinerja propeller.
\end{abstract}

Kata Kunci: gas buang; temperature; UAV; propeller; kayu

Received : 04 June 2020, Revised : 13 July 2020, Accepted : 29 July 2020

\section{INTRODUCTION}

PUNA Alap-alap is one of multi-purpose UAV. One of the main missions is to conduct mapping missions. For mapping mission, this basic standard configuration UAV will be equipped with a payload system such as a (camera ${ }^{1}$. PUNA Alap - alap is equipped with a propulsion system. In this UAV, propulsion system consists of an engine, propeller, engine mounting, fuel tank and fuel pipes. Propeller is an arrangement of rotating airfoil blades and it is useful for inducing drag, stall, and other aerodynamic forces applied to each airfoil. The function of propeller blades is to assist power transmission by converting the rotational motion into thrust. The blades are attached to the hub2). The material used in propeller blades may be of various types, some of them are wood, aluminium, or 
composites. Wood has the characteristics of strength to weight ratio and ultimate strength that is not affected by fatigue. Beechwood is a material that can be used as a propeller blade. Beechwood is one of the hardwoods with a density of $154 \mathrm{~kg} / \mathrm{m}^{3}{ }^{3}$ ). At temperatures of $70-200^{\circ} \mathrm{C}$ for $6-24$ hours, water absorption decreases at temperatures higher than $100^{\circ} \mathrm{C}^{4}$ ). The reduction in water absorption, effects in depreciation reduction and expand in wood, or in other words it will increase the stability of the dimensions of wood $^{5}$. The CNC manufacturing process is used to make propeller blades from this material, then coated a primary layer and a protective layer to prevent corrosion.

UAV propulsion system is very important. The working operation of propeller affects the performance of $U A V^{6}$. The exhaust temperature that reaches almost $100^{\circ} \mathrm{C}$ will interact directly with the propeller. So excessive heat and continuous discharge from the exhaust system can cause the worst scenario of the propeller blade damage. Fortunately, the highest temperature is below the maximum allowable operating temperature of the blade material used. Nevertheless, these results give no guarantee that there will be no thermal damage occurring on the propeller. Therefore, there is still a need to improve the safety and performance of UAV, for example by overcoming direct thermal interactions on the propeller.

In this study, it was focused on how to assess the influence of the exhaust gas temperature on the fixed-pitch propeller material. The goal is to investigate the performance of the propeller on long-range missions. Gun temperature is used to measure the temperature of the propeller.

\section{EXPERIMENTAL METHOD}

Steady dynamic analysis on fixed-pitch pusher propeller has been carried out in the Hangar PTIPK-BPPT, Puspiptek. The Propeller model consists of two wooden blades with a diameter of $558.8 \mathrm{~mm}$. The exhaust of engine position is located at $57.7 \%$ of the propeller tip radius from the propeller centre line. The distance from the front exhaust to rear exhaust is $40 \mathrm{~mm}$. The distance from the rear exhaust point to propeller disk is $60 \mathrm{~mm}$. This exhaust position when projected into the propeller disk, is marked in blue. The marking rotates following the propeller slip flow as shown in Figure 1.
Besides the heat effect, the discharge effect against pusher propeller must also consider the foreign object damage caused by the exhaust. When the propeller is made of metal it will cause corrosion. However, the propeller in this study is wooden blades, so the effect of the foreign object can be ignored. During the maximum open throttle, the resulting exhaust gas temperature is $100^{\circ} \mathrm{C}$, located at a $100 \mathrm{~mm}$ downstream exhaust.

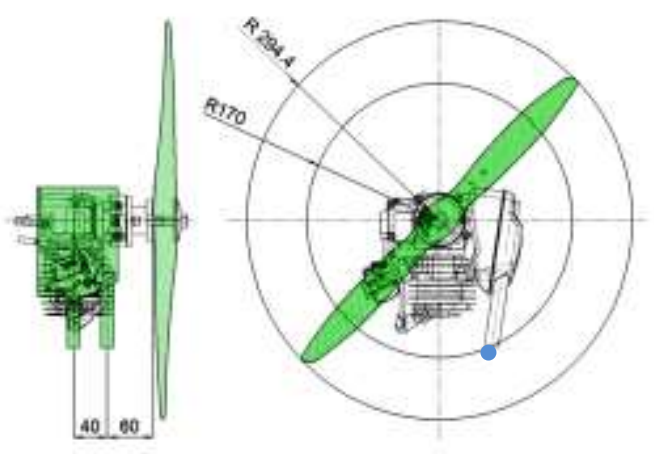

Figure 1.

Effect of Exhaust Temperature Against Pusher Propeller

The test conditions in this study is shown in table 1.

Table 1.

Experimental Conditions

\begin{tabular}{lc}
\hline Parameters & Annotation \\
\hline Max. Fuel (litter) & 9 \\
Max. Payload $(\mathrm{kg})$ & 2 \\
Engine Power (HP) @ 7200 & 4.2 \\
The Type of Propeller & Pusher \\
Blade setting angle (deg) & 0 \\
Blade pitch (mm) & 254 \\
Outdoor air temperature $\left({ }^{\circ} \mathrm{C}\right)$ & 30 \\
\hline
\end{tabular}

The propulsion system is connected with several components, among others, engine system, pusher-propeller, engine control, fuel system, instrumentation and ignition. PusherPropeller installations have been proven to offer some advantages at the aircraft level in terms of cost, weight and aerodynamic consideration ${ }^{7}$. The engine used were 2stroke engines with the air-cooled and oilfuel mixture with a ratio of 1:30. Fuel is poured through the filter. The use of metal fuel cans will cause corrosion. Particles of rust, which enter the fuel system might block the fuel supply, resulting in an unsafe operating condition also the engine might be 
permanently damaged. Ground clearance is the distance between the tip of propeller and ground with the landing gear statically deflected and, in the level, normal take-off, or taxing attitude, whichever is most critical. The Ground clearance in this study is 82 $\mathrm{mm}$.
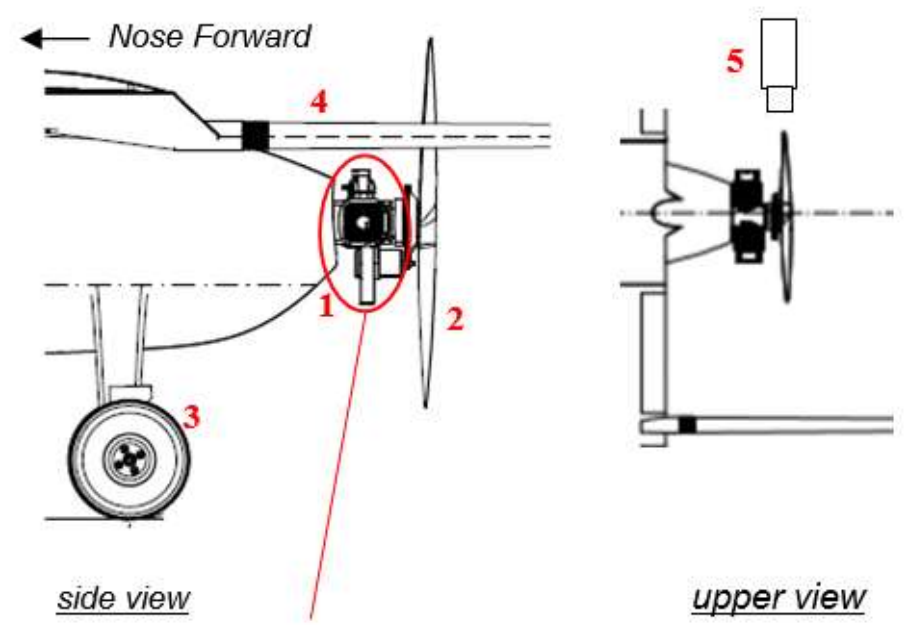

FUEL PUMP INTAKE

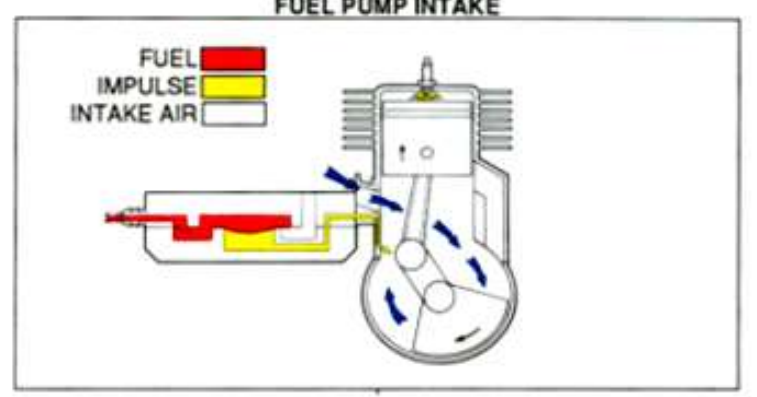

Information:

1. Engine

2. Pusher Propeller

3. Main Landing Gear

4. Tail boom

5. Fluke Gun

Figure 2.

Scheme of Exhaust Temperature on Propeller

Once the engine is starting it built vacuum pressure in the engine side, low pressure on the plate and high pressure (ambient pressure). Fuel is pumped by the air pressure via the vent cavity. Fuel is mixed with air delivered to the crankcase and compressed by piston movement. When maximal rpm is reached, the subsequent temperature is recorded on the engine and propeller area using Fluke gun. The gun is directed to the media or objects to be measured its temperature, then infrared from this gun will read the temperature of the media. For highest accuracy, it's best to allow some time for Fluke Gun to come to the temperature of its surroundings when bringing into surroundings that are significantly warmer or colder than where it has been stored.

On the condition by performing variations of the throttle opening, acquired total thrust. The condition affects significantly the exhaust temperature. The propeller thrust is shown in Table 2. 


\begin{tabular}{lccc}
\hline $\begin{array}{l}\text { Propeller } \\
\text { type }\end{array}$ & Throttle & $\begin{array}{l}\text { RPM } \\
\text { Max }\end{array}$ & $\begin{array}{c}\text { Thrust Total } \\
\text { (+Resistance = 1.6 Kg) }\end{array}$ \\
\hline & $50 \%$ & 5000 & $7.85 \mathrm{~kg}$ \\
\cline { 2 - 4 } $22 " \times 10 "$ & & 6100 & $11.05 \mathrm{~kg}$ \\
& $100 \%$ & 6000 & $11.25 \mathrm{~kg}$ \\
& & 6000 & $11.10 \mathrm{~kg}$ \\
\hline
\end{tabular}

\section{THEORETICAL STUDY}

The propeller efficiency and power availability of the UAV are proportional to the cruising speed when the altitude of flight is constant, and the efficiency and power availability are proportional to the opposite of the flight altitude when the cruising speed is certain.

The creation of the medium speed UAV, require the processes of heat transfer. Based on the three types of convective heat transfer, for the best efficiency, forced convection is often used. In contrast, natural convection has a free advantage in terms of energy costs but results in a low heat transfer coefficient. Thus it would be interesting to increase the free convection heat transfer, over time-dependent boundary conditions.

The convective heat transfer coefficient for inside and outside area are resulting from an empirical correlation for laminar and fully developed turbulence, turbulent flow. The Major heat transfer parameters for Local Nusselt number $(\operatorname{Pr}>0.6)$ at a uniform surface temperature in laminar flow, is defined by the equation:

$N u=0.332 \times(R e)^{1 / 2} \times(P r)^{1 / 3}$

While local Nusselt number $(\operatorname{Pr}>0.6)$ for uniform surface temperature in turbulent flow, is defined by the equation:

$$
N u=0.023 \times(R e)^{0.8} \times(\operatorname{Pr})^{0.3}
$$

\section{ANALYTICAL STUDY}

Calculations are conducted by referring literature. In this calculation, the initial data is defined as follows, diameter propeller $\left(D_{p}\right)=$ $588.8 \mathrm{~mm}$, the distance from wing to the propeller $(\mathrm{H})=0.042$, the exhaust temperature is $100^{\circ} \mathrm{C}$, ambient temperature is $30^{\circ} \mathrm{C}$, and velocity $(\mathrm{V})$ is $28.3 \mathrm{~m} / \mathrm{s}$, By taking the properties of exhaust gases at a certain temperature thus the calculation to be prepared are density ( $\rho) 1.164 \mathrm{~kg} / \mathrm{m}^{3}$, viscosity $(\mu)=18.6 \times 10^{-6} \mathrm{Ns} / \mathrm{m}^{2}$ or $\mathrm{Pa} \mathrm{s}$, thermal conductivity $(k)=0.0516 \mathrm{~W} / \mathrm{m} . \mathrm{k}$, and Prandtl $(\operatorname{Pr})=0.6463$.

Reynolds number:

$R e=\frac{\rho \times V \times D}{\mu}=104278$

The flow that comes towards UAV is:

$\mathrm{Nu}=0.023 \times(\mathrm{Re})^{0.8} \times(\mathrm{Pr})^{0.3}$

$\mathrm{Nu}=208.647$

The equation of Nusselt number ${ }^{8)}$ was developed by Martin as follows:

$N_{\text {uavg }}=P r^{0.42} \frac{D}{r} \frac{1-1.1 D / r}{1+0.1\left(\frac{H}{D}-6\right) D / r} F$

where $2000<\operatorname{Re}<400000$.

For $30000<\operatorname{Re}<120000$, the value of $F=$ $0.54 \mathrm{Re}^{0.667}$, where $\mathrm{F}$ is friction factor ${ }^{9)}$.

From above equation resulting (the ratio of radius surface area to the diameter blade):

$$
r / D=4.103
$$

Goldstein et al. ${ }^{10)}$ gives a correlation between effectiveness and temperature, as follows:

$$
\begin{aligned}
\text { Effectiveness } & =1.193(\mathrm{r} / \mathrm{D})^{-0.98} \text { when } \mathrm{r} / \mathrm{D} \geq 3.5 \\
& =0.299 \\
\text { Effectiveness } & =\frac{T_{\text {ref }}-T_{\text {amb }}}{T_{\text {exh }}-T_{\text {amb }}}
\end{aligned}
$$

Therefore, $T_{\text {ref }}=50.93^{\circ} \mathrm{C}$ is the temperature at the propeller.

\section{RESULTS AND DISCUSSIONS}

In this study, the analytical study shows the reference temperature (Tref), which is 
the temperature of UAV propeller facing the exhaust gas flow. When compared with experimental results, as shown in Figure 3 , it is observed that the exhaust gas flow shows that the engine and installed propeller affect the exhaust gas will be directed to the propeller with the maximum temperature of $100^{\circ} \mathrm{C}$.

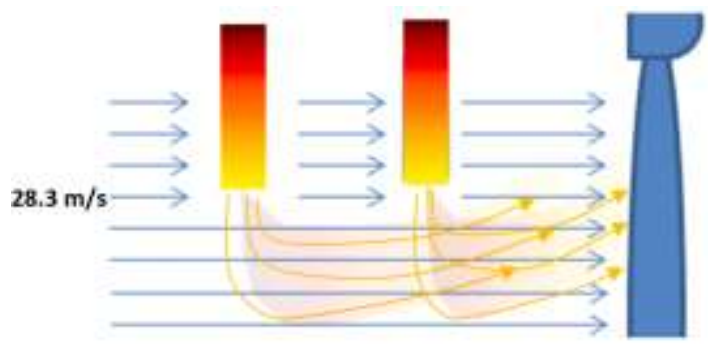

Figure 3.

Exhaust Discharge Model

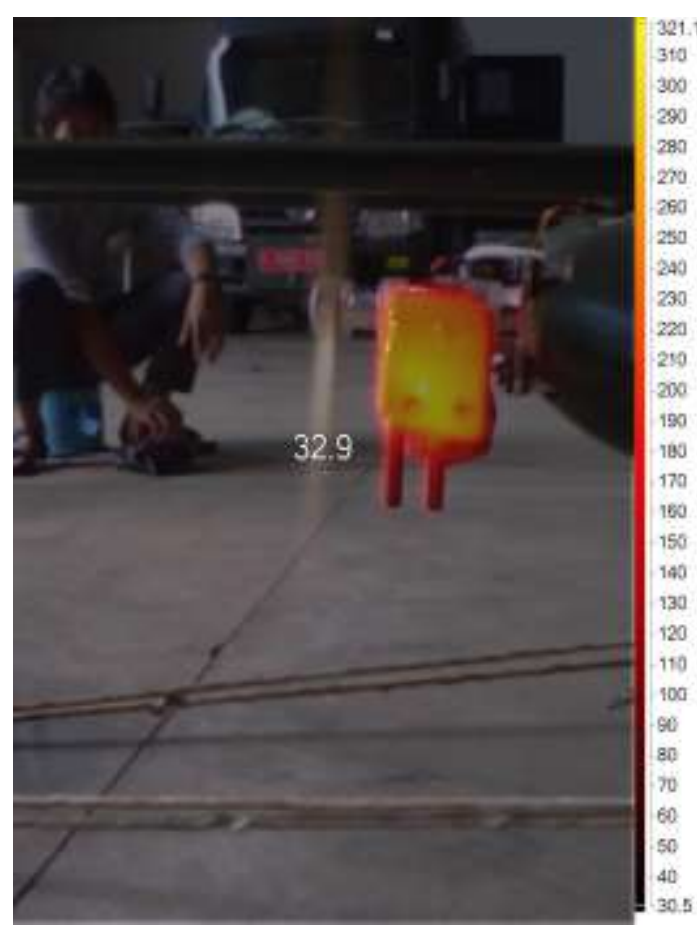

Figure 4.

Temperature Contour - Exhaust Discharge (Engine and Prop)

In static condition, thermal stress will cause to accelerate the production of flammable gas from the wood propeller. Actually, propeller is rotated therefore the thermal stress is always released. Qualitatively, the pusher propeller is noisier due to the exhaust noise flows through the propeller and magnifies due to air flow irregularity behind the propeller.

The analysis was carried out and conservatively the propeller was heated to $32.9^{\circ} \mathrm{C}$. Effect of the exhaust gas to pusher propeller on UAV does not affect to the propeller performance, considering the heat received by the propeller is still below the permitted temperature.

\section{CONCLUSION}

The maximum air flow or speed contour combine with the exhaust gas flow shows that with the engine and installed propeller, the exhaust gas will directed to the propeller with the maximum temperature of $50.93^{\circ} \mathrm{C}$.

A Beechwood pusher Propeller with a protective layer of corrosion prevention on PUNA Alap-alap experiences direct contact with heat from that exhaust gas. In this study, effect of the exhaust gas to pusher propeller does not affect to the propeller performance.

\section{ACKNOWLEDGEMENT}

The author gratefully acknowledge the support provided for PUNA team with their assistance in experimental data collection and the assistance by Director of PTIPKBPPT.

\section{REFERENCES}

1. Suroso, I., \& Irmawan, E. Analysis Of Aerial Photography With Drone Type Fixed Wing In Kotabaru, Lampung. Journal of Applied Geospatial Information, 2(1), 102-107, 2018.

2. Madhusudhan, B.M., and Srihari, P.V., Design and analysis of Composite propeller Blade for aircraft, International Journal of Engineering Research and Applications, Vol. 4, Issue: 9, p.79-82, September 2014.

3. Markwardt, L.J., Aircraft Woods: Their Properties, Selection, and Characteristics, NACA Report No. 354, Reprint U.S. Department of Agriculture, Forest Products Laboratory, Report No. 1079, October 1941.

4. Kollmann, F.F.P, and Schneider, A., On the Sorption Behaviour of Heat Stabilized Wood, Holz Roh-Werkst, Vol. 21, Issue: 3, p.77-85, 1963.

5. Kocaefe, D., Poncsak, S., Dore, G., and Younsi, R., Effect of Heat Treatment on Wettability of White Ash and Soft Maple by Water, Holz Roh Werkst, Vol. 66, p.355-36, 2008.

6. Liu, R. L., Zhang, Z. J., Jiao, Y. F., Yang, C. H., \& Zhang, W. J. (2019). Study on Flight Performance of Propeller-Driven UAV. International 
Journal of Aerospace

Engineering, 2019.

7. Malia, M., Vinay, C.A., Chougulea, A., and Kadama, S., CFD Study of Propeller Blade Temperature for Pusher Configured Turbo-Prop Engine, THERMACOMP2018, Indian Institute of Science, Bangalore, India, July 2018.
Duct with Different Boundary Heating. Engineering and Technology Journal, 30(6), 1082-1107.

10. Goldstein, R.J., Sobolik, K.A., and Seol, W.S., Effect of Entrainment on the Heat Transfer to a Heated Circular Air Jet Impingement on a Flat Surface, Journal of Heat Transfer, Vol. 112, p.608-11, 1990.

8. Martin, H., Heat and Mass Transfer between Impinging Gas Jets and Solid Surfaces, In Advances in Heat Transfer, Elsevier, Vol. 13, p.1-60, 1977.

9. Hilal, K. H. (2012). Experimental Investigation of Heat Transfer and Pressure Drop in Square Metal Packed 